\title{
OPTIMISME DALAM KOLABORASI SENI DAN PSIKOLOGI ANAK
}

\author{
Moch. Aan Machfudzi \\ Program Studi Magister Penciptaan dan Pengkajian Seni \\ Institut Seni Indonesia Yogyakarta \\ Email: aan.fudzi@gmail.com
}

\begin{abstract}
The existence of children illustration book gives a major contribution to children's psychology development, appreciation, and imagination due to the efficient and effective characteristics of the book. Bella Ansori is one of the illustrators from Malang who makes children illustration book as the media to express her anxiety experienced by herself related to children's psychology. Based on the above background, this writing aims at identifying and understanding creative process in designing illustration work that has done by Bella Ansori, in order to contribute positively to all of Indonesians.
\end{abstract}

Keywords: book, illustration, psychology, child

\begin{abstract}
Abstrak: Hadirnya buku ilustrasi anak memiliki andil besar terhadap perkembangan psikologi, apresiasi, dan imajinasi anak-anak karena bersifat efektif dan efisien. Bella Ansori adalah salah seorang ilustrator dari Kota Malang yang menjadikan buku ilustrasi anak sebagai media untuk mengekspresikan keresahan-keresahan yang ia alami berkaitan dengan psikologi anak. Berdasar dari latar belakang tersebut, tulisan ini bertujuan untuk mengidentifikasi dan memahami proses kreatif dalam merancang karya ilustrasi yang dilakukan oleh Bella Ansori, sehingga dapat memberikan kontribusi positif bagi seluruh masyarakat Indonesia.
\end{abstract}

Kata kunci: buku, ilustrasi, psikologi, anak

\section{PENDAHULUAN}

Periode anak-anak merupakan periode yang unik karena proses tumbuh kembangnya terjadi secara bersamaan antara pertumbuhan fisik dan perkembangan psikologisnya atau yang biasa disebut dengan golden age period. Menurut Helms dalam buku Exploring Child Behavior (199, p. 64), periode anak-anak merupakan fase sense of initiative. Pada periode ini anak harus diberi stimulus agar dapat mengembangkan inisiatifnya, seperti kegemaran anak-anak dalam berpikir kritis, sehingga mereka sering sekali mengajukan pertanyaan-pertanyaan dari apa yang mereka lihat, dengar, dan rasakan.

Pertumbuhan dan perkembangan pada anak sangat penting dijadikan perhatian bagi semua kalangan, sebab proses tumbuh kembang anak akan mempengaruhi kehidupan mereka pada masa yang akan datang. Meskipun pertumbuhan dan perkembangan pada anak terjadi secara bersamaan, tidak menutup kemungkinan perkembangan aspek kepribadian pada anak akan berkembang secara acak atau saling mendahului. Di dalam aspek kepribadian itu sendiri terdapat beberapa aspek yang yang mempengaruhi perkembangan tiap anak yaitu aspek intelektual, fisik, psikologi, bahasa, moral, dan agama. Aspek psikologi anak memiliki peranan yang sangat sensitif bagi anak, di mana fungsi tertentu dalam perkembangan anak perlu dirangsang dan diarahkan.

Psikologi anak berkembang melalui interaksi secara langsung dengan lingkungannya. Anak belajar melalui imitasi, mencoba, dan mengalami terhadap orang terdekat mereka. Eksistensi orang tua merupakan faktor lingkungan yang paling mendominasi perkembangan aspek psikologi pada anak. Dalam hal ini, adanya kontrol dari luar seharusnya didominasi oleh peranan orangtua dalam memberikan pendampingan perkembangan psikologi untuk anak. Namun dewasa ini bukan hal yang baru lagi ketika jumlah orangtua terutama ibu yang lebih memilih karir daripada keluarga semakin meningkat. Selain itu adanya pola asuh 
orangtua dalam mendidik anak dengan kekerasan atau penganiayaan serta keadaan sosial ekonomi keluarga yang tidak dapat menjamin kenyamanan anak, merupakan permasalahan-permasalahan yang seharusnya tidak terjadi di lingkungan anak dalam proses tumbuh kembangnya. Padahal, menurut Indrijati (2017, p. 113) keluarga (orangtua) merupakan lingkungan pertama dan utama dalam memberi pembinaan tumbuh kembang anak, menanamkan nilai moral, dan pembentukan kepribadian.

Selain kontrol yang diberikan oleh orangtua, ada beberapa kontrol dari luar yang dapat mempengaruhi prakarsa yang dilakukan anak. Menurut Marliani (2016) dan Indrijati (2017) kontrol dari luar tersebut antara lain lingkungan masyarakat (sosial) meliputi pertemanan dan kehidupan bersosialnya, lingkungan sekolah meliputi peranan guru dan proses belajar mengajarnya, serta peran media meliputi media elektronik maupun media sosial yang menyajikan berbagai hiburan yang tentunya membawa dampak positif dan negatif bagi tumbuh kembang anak.

Keberagaman kontrol dari luar tersebut juga berpengaruh terhadap bagaimana anak berkembang dan belajar dari lingkungan. Rangsangan yang diberikan kepada anak haruslah seimbang dan sesuai dengan kebutuhan, karena disorientasi dapat terjadi pada perkembangan psikologis anak jika dalam pemberian stimulasi tidak seimbang. Misalnya seperti orangtua yang menggunakan kekerasan fisik ketika anak tidak dapat melakukan sesuatu yang diperintahkan oleh orang tuanya atau orang tua dengan gaya pengasuhan otoritarian yang dapat mengakibatkan anak cenderung tidak puas, menarik diri, dan percaya kepada orang lain (Indrijati, 2017). Disorientasi juga dapat terjadi karena pemberi kontrol tidak menguasai capaian sebuah perkembangan psikologi pada anak. Pemberian stimulasi oleh pemberi kontrol harus sesuai dengan karakteristik perkembangan anak, tidak hanya berdasar pada kepentingan orang tua, maupun lingkungan di sekitar anak.

Melihat urgensi yang terjadi pada anakanak tersebut, membuat Bella Ansori tergerak untuk peduli terhadap perkembangan psikologis anak. Keinginannya membantu anak-anak dalam mendapatkan hak-haknya untuk bertumbuh dan berkembang serta mendapatkan perlindungan dari segala bentuk kekerasan, eksploitasi, dan diskriminasi sangatlah besar. Menurutnya, anak-anak harus mendapat perlindungan penuh dari semua lapisan masyarakat terutama lingkungan keluarga.

Bella Ansori merupakan ilustrator buku anak asal Kota Malang yang mayoritas karyakaryanya diciptakan untuk menjawab kepeduliannya terhadap perkembangan psikologi anak. Bella Ansori juga bekerjasama dengan beberapa penerbit buku besar dalam penciptaan karyanya, dengan cara tersebut ia dapat dengan mudah merealisasikan visi misinya dalam membentuk opini masyarakat bahwa buku ilustrasi anak merupakan media yang sangat relevan dan efektif untuk mengembangkan psikologi anak. Tujuan dari penelitian ini adalah untuk mengetahui, mengidentifikasi, dan memahami latar belakang serta proses kreatif Bella Ansori sebagai ilustrator buku anak dalam membantu anak-anak Indonesia mendapatkan hak tumbuh kembangnya.

\section{METODE}

Metode yang digunakan dalam penelitian ini adalah metode kualitatif. Menurut Creswell (2016) metode kualitatif memiliki prosedur pelaksanaan penelitian yang dilakukan melalui beberapa tahap, antara lain pengambilan sampel secara sengaja, pengumpulan data terbuka, analisis, penyajian informasi, serta interpretasi atas temuan-temuan. Subjek dipilih dengan selektif dari beberapa subjek yang tersedia. Kemudian dilakukan pelaksana penelitian dengan melakukan pendekatan wawancara by phone karena keterbatasan waktu dan jarak, dalam wawancara ini dilakukan pula pengumpulan informasi tentang pengkaryaan buku ilustrasi anak yang diciptakan subjek terhadap perkembangan psikologis anak. Wawancara ini dilakukan untuk mendapatkan informasi valid mengenai latar belakang pengkaryaan, proses kreatif pengkaryaan, dan optimisme dalam pengkaryaan.

\section{PEMBAHASAN}

\section{Bahasa Visual dan Psikologi Anak}

Desain Komunikasi Visual menurut Tinarbuko (2015) merupakan ilmu yang mempelajari konsep komunikasi dan ungkapan 
daya kreatif, yang diaplikasikan dalam berbagai media komunikasi visual dengan mengolah elemen desain grafis yang terdiri dari gambar (ilustrasi), huruf, warna, komposisi, dan layout. Penyampaian tersebut dilakukan untuk mengkomunikasikan pesan secara visual maupun audio visual kepada target sasaran yang dituju, agar target sasaran dapat menangkap informasi yang akan disampaikan secara cepat dan tepat. Rittie (2000) dalam jurnalnya yang berjudul The Verbal and Visual Components of Package Design juga berpendapat, bahwa persepsi manusia didominasi oleh otak kanan yang memiliki penampang lebih luas, artinya lebih cepat menangkap sesuatu yang bersifat nonverbal (visual) daripada verbal.

Di dalam tubuh desain komunikasi visual sendiri terdapat sistem komunikasi yang digunakan untuk menjembatani pesan dengan target sasaran. Sistem komunikasi tersebut disebut dengan bahasa visual. Bahasa visual yang hadir pada media desain komunikasi visual -salah satunya ilustrasi- perlu memperhatikan mengenai tata cara penyajian visual yang mudah dicerna dan dipahami bagi mata pembaca sehingga audiens dapat menginterpretasikannya secara mandiri. Penggunaan bahasa visual oleh seorang ilustrator dapat diasosiasikan dengan gaya gambar tertentu. Gaya gambar ini dapat mewakili ilustrator dalam mengenalkan identitas dirinya kepada audiens sekaligus sebagai media untuk menginformasikan genre ilustrasi dari ilustrator tersebut.

Seiring dengan berkembangnya ilmu pengetahuan dan pendidikan, bahasa visual pada ilustrasi tidak hanya digunakan sebagai wakil dari identitas perancangnya, namun juga digunakan untuk merekam dunia fisik dan intelektual yang dikemas dalam bentuk buku pendidikan, ensiklopedi, dan keilmuan. Bahasa visual digunakan para ilmuwan dalam merepresentasikan secara detail subjek yang diteliti. Selain itu bahasa visual juga digunakan untuk mengubah cara pandang seseorang dalam menyikapi sebuah fenomena. Kekuatan persuasi tidak bisa dianggap remeh dan bahasa visual selama ini mengambil peran yang besar dalam hal ini.

Peran ilustrator sebagai perancang sangatlah penting, ia harus cermat dalam memvisualkan secara detail pada setiap bagian dari naskah dengan memperhatikan keseimbangan antara teks dan gambar. Menurut Elster dan Simons (1985) ketika gambar dan teks saling berinteraksi, maka mereka dapat mempengaruhi kemampuan membaca untuk memahami cerita dengan baik sekaligus dapat mempengaruhi psikologi pembaca oleh sajian dari teks dan gambar tersebut.

Seperti pada semua bidang penelitian ilmiah lainnya, pengaruh bahasa visual pada perkembangan psikologi khususnya psikologi anak juga memiliki berbagai sudut pandang yang didukung oleh perspektif dan teori masing-masing. Teori dan perspektif ini membentuk pemahaman dan pengertian kita terhadap tumbuh kembang anak yang berubah seiring dengan perubahan waktu. Beberapa teori menyebutkan bahwa tumbuh kembang yang terjadi pada anak dipengaruhi oleh faktor internal yang terjadi secara biologis dan faktor eksternal yang merupakan pemicu tumbuh kembang anak.

Menurut Marliani (2016:141) faktor utama perkembangan anak dan remaja adalah hereditas yang diperoleh dari orangtuanya. Selain hereditas, lingkungan merupakan faktor penting yang menentukan perkembangan dari setiap anak dan remaja. Faktor lingkungan meliputi lingkungan fisik, psikis, sosial, dan religius.

Kedudukan bahasa visual pada perkembangan anak berada di wilayah psikis. Oleh sebab itu beberapa ilustrator memanfaatkan bahasa visual dalam karya ilustrasinya agar dapat mempengaruhi psikologi pembacanya dalam hal ini anakanak. Karya ilustrasi yang melibatkan seni dan psikologi anak berkembang sangat pesat hingga saat ini. Pada akhir tahun 1990 hingga tahun 2000 dunia ilustrasi anak kembali menjadi populer di dunia desain dan seni rupa. Ilustrator menemukan peran baru di dunia new media dan animasi. Christian Robinson, Bethan Woollvin, dan Duncan Tonatiuh merupakan beberapa nama ilustrator yang mengkolaborasikan seni dan psikologi anak yang cukup dikenal karena karakter visualnya. Christian Robinson dikenal dengan gaya ilustrasi digital sederhana, Bethan Wolvin dikenal dengan gaya ilustrasinya yang terkonsep, dan Duncan Tonatiuh dengan ilustrasinya dengan tema kehidupan anak 
Meksiko. Selain itu ada juga Cyril Rolando, seorang ilustrator sekaligus psikolog asal Perancis yang mengkolaborasikan seni dan psikologi dalam ilustrasi digital. Cyril memulai menggambar saat ia memulai studi psikologinya dan menjadi seorang psikolog. Ia berpikir bahwa seni dan psikologi dapat saling melengkapi dan menjadi kombinasi yang indah.

Di Indonesia sendiri ilustrasi modern berkembang sejak tahun 1917 yang tumbuh di bawah payung Penerbit Balai Pustaka, seperti Ardisoma, Abdul Salam, Kasidi, dan Nasroen. Selain itu pada tahun 1980 -an, penulis buku dan ilustrator anak di Indonesia semakin banyak yang mengorbit. Sebut saja Arswendo Atmowiloto, Bung Smas, dan Dwianto Setyawan di bawah bendera Penerbit Gramedia.

\section{Bella Ansori dan Buku Ilustrasi Anak}

Bella Ansori merupakan seorang ilustrator asal Kota Malang yang memiliki fokus berkarya pada buku ilustrasi anak yang memadukan ilmu psikologi perkembangan anak dengan bahasa visual yang sederhana. Pengkolaborasian lintas disiplin ilmu tersebut diilhami oleh keresahan yang dialaminya ketika masa anak-anak terhadap problematika keluarga, lingkungan, dan masyarakat tempat Bella tinggal.

Rasa empatinya terhadap perkembangan psikologi anak, khususnya dalam membantu anak-anak mendapatkan hak-hak tumbuh kembang mereka serta mendapatkan perlindungan dari segala bentuk kekerasan, eksploitasi, dan diskriminasi dari semua lingkungan terutama lingkungan keluarga, membuatnya selalu mengeksplorasi gaya maupun metode dalam berkarya. Menurutnya, menciptakan sebuah karya ilustrasi tidak hanya berlandaskan pada estetika dan idealis penciptanya, namun juga harus bermanfaat bagi lingkungan di sekitarnya.

Oleh karena itu Bella Ansori memilih buku ilustrasi anak sebagai media untuk menyampaikan keinginannya dalam membantu anak-anak Indonesia mendapatkan hak tumbuh kembang mereka khususnya dalam hal perkembangan psikologi. Menjadi seorang ilustrator buku anak merupakan sebuah langkah radikal yang diambil Bella Ansori dalam menyikapi pengalaman- pengalaman pahit masa lalu yang pernah dialaminya.

Misalnya terjadinya problematika pada faktor ekonomi keluarga sehingga tidak dapat menyelesaikan hutang piutang pada keluarga Bella yang berdampak pada penyitaan aset-aset pribadi milik keluarganya, terjadi kekerasan fisik dan pelecehan seksual yang dialami oleh teman-temannya dan dirinya sendiri ketika masih anak-anak yang dilakukan oleh masyarakat bahkan pemuka agama di lingkungan tempat tinggalnya, sulitnya mendapatkan media pendukung dunia imajinasi anak untuk anak-anak dengan latar belakang keluarga ekonomi yang rendah, serta minim sekali ketersediaan media yang dapat menunjang perkembangan psikologi anak yang ia miliki di masa kecil.

Melihat permasalahan-permasalahan tersebut membuatnya menentukan sikap untuk menjadi seorang ilustrator buku anak. Bella tidak ingin anak-anak di sekitarnya mengalami hal yang sama seperti apa yang pernah dialaminya. Oleh sebab itu, ia tergerak untuk memberikan solusi atas permasalahanpermasalahan yang terjadi di lingkungan tempat tinggalnya maupun tempat tinggal anak-anak Indonesia lainnya.

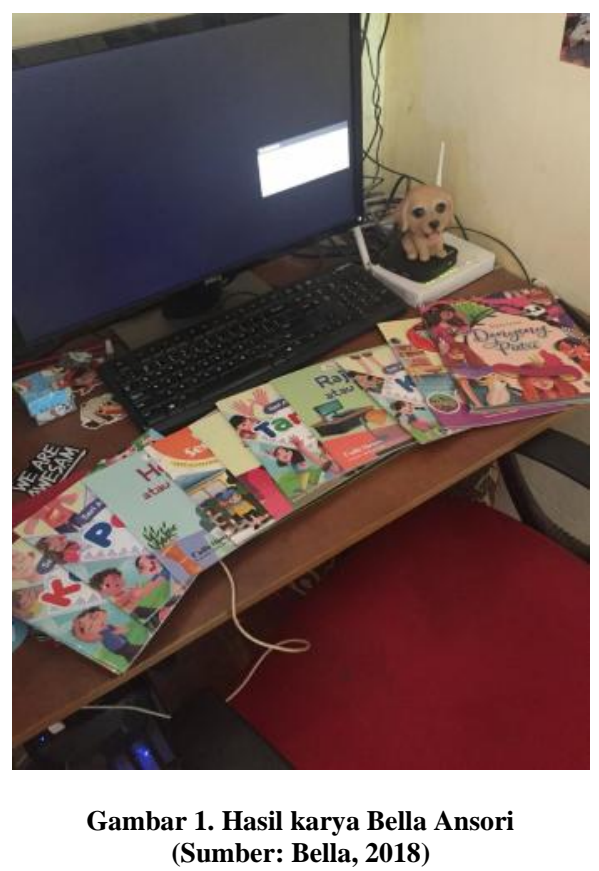

Ia juga berharap dengan adanya media buku ilustrasi anak ini, generasi muda khususnya anak-anak tidak terpengaruh 
dengan tayangan televisi dan media sosial yang dewasa ini kontennya mayoritas tidak layak untuk dikonsumsi oleh anak-anak. Selain itu, ia juga berharap dengan adanya karya-karya buku ilustrasi anak yang ia rancang, nantinya dapat berpengaruh positif pada masa kecil anak-anak minimal di lingkungan tempat tinggalnya.

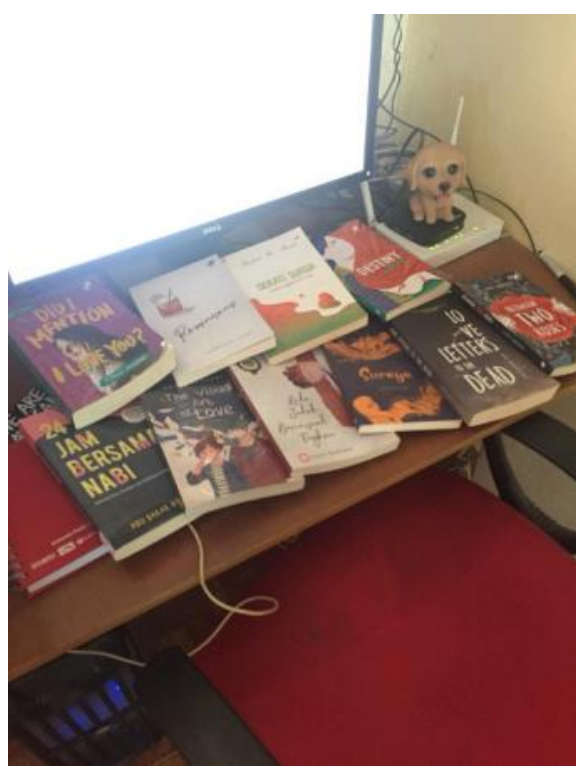

Gambar 2. Hasil karya Bella Ansori (Sumber: Bella, 2018)

\section{Proses Kreatif}

Keresahan Bella Ansori terhadap masa anak-anak di lingkungan maupun pengalaman pribadinya seperti yang sudah disebutkan pada sub bab sebelumnya, membuatnya terdorong untuk peduli terhadap perkembangan psikologis anak. Perspektifnya dalam melihat permasalahan ini memberikannya sebuah ide dalam mencari sebuah solusi untuk memecahkan masalah polemik tersebut. Ia memanfaatkan keahlian dalam bidang ilustrasi yang ia kuasai dengan merancang sebuah media yang dapat mempengaruhi psikologis anak ke arah yang lebih positif yaitu buku ilustrasi anak.

Perancangan suatu karya tentunya membutuhkan proses di dalamnya. Tahapan yang dilakukan Bella Ansori dalam perancangan karya buku ilustrasi anak ini terbagi dalam beberapa tahap yaitu penetapan tujuan dan konsep, observasi materi, proses pra produksi, dan proses produksi. Tahap pertama yaitu penetapan tujuan dan konsep, dimana ia menetapkan hasil akhir yang akan dicapai dalam pembuatan karya buku ilustrasi anak, yaitu sebagai media pengembangan psikologi anak. Pada tahap ini ia juga mempelajari lebih dalam lagi akan konsep yang telah ia buat maupun konsep yang telah diberikan oleh penulis naskah.

Setelah penetapan tujuan dan konsep sudah matang, tahap berikutnya adalah observasi materi. Observasi materi merupakan tahapan yang dilakukan untuk mengumpulkan dan meninjau informasi-informasi penting yang akan divisualkan, baik berupa tokoh manusia, hewan, tumbuhan, latar belakang, maupun materi pendukung lainnya, serta melakukan pengamatan secara cermat tentang metode yang tepat untuk mengkomunikasikan pesan pendidikan psikologi anak.

Tahap ketiga adalah proses praproduksi, pada tahap ini Bella Ansori menentukan konsep karakter yang akan dimasukkan dalam buku ilustrasi anak. Selain konsep karakter, latar belakang, dan color mood juga disusun sedemikian rupa agar terbentuknya landasan visual dalam berkarya. Dalam tahap ini proses sketsa juga dilakukan dengan menggunakan beberapa software ilustrasi dan desain seperti Adobe Photoshop, Adobe Illustrator, dan Easy Paint Tool SAI. Selain menggunakan software digital tersebut, ia juga menerapkan proses sketsa manual drawing pada proses kreatif perancangan buku ilustrasi anak.
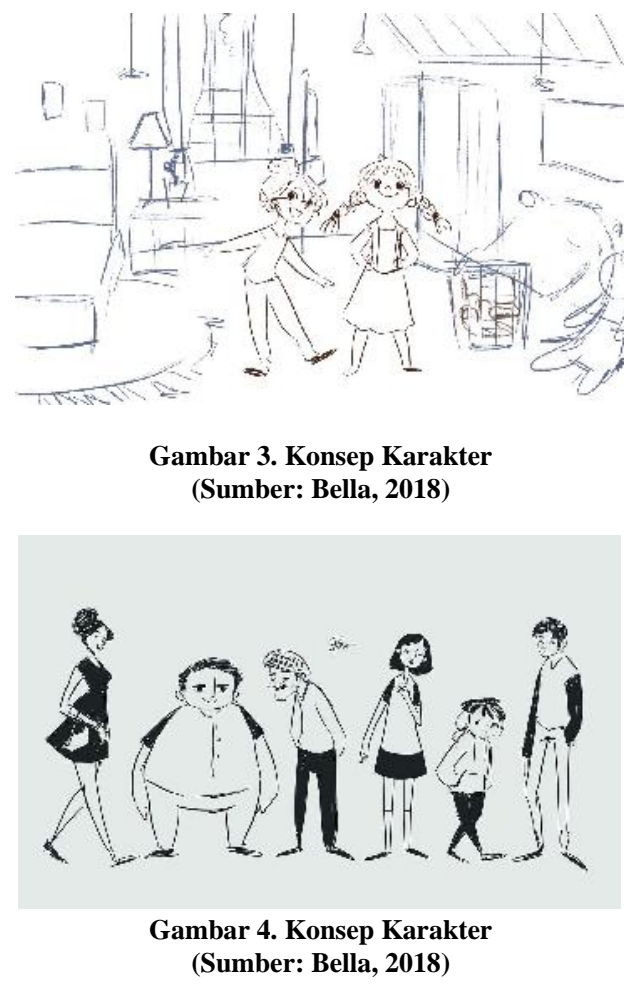
Tahap terakhir adalah proses produksi dimulai dari filling objek pada sketsa yang sudah dilakukan pada tahap sebelumnya, lalu detailing, dan terakhir proses rendering. Setelah proses rendering, tahapan selanjutnya adalah tahap uji coba warna dan ukuran dengan cara dicetak sebagai bagian dari blueprint sebelum diproduksi massal.

Teknik yang menjadi acuan Bella Ansori dalam merancang karya buku ilustrasi anak adalah teknik digital painting dan digital drawing. Ia juga memiliki kiblat dalam gaya pengkaryaan. Disney style atau American style yang berpijak pada aliran surealisme dipilih Bella sebagai kiblat dari gaya pengkarya nya karena memiliki objek visual yang sederhana sehingga mudah diterima oleh mata pembaca. Karya-karya Bella Ansori juga dipengaruhi oleh gaya beberapa ilustrator seperti Beatrice Blue, Mr. Daniez, Salulu Art, Sarkodit, dan beberapa ilustrator dunia lainnya yang merujuk pada aliran surealisme.

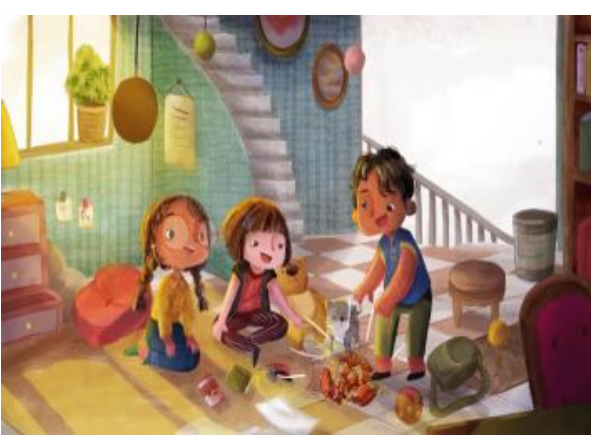

Gambar 5. Hasil karya Bella Ansori (Sumber: Bella, 2018)

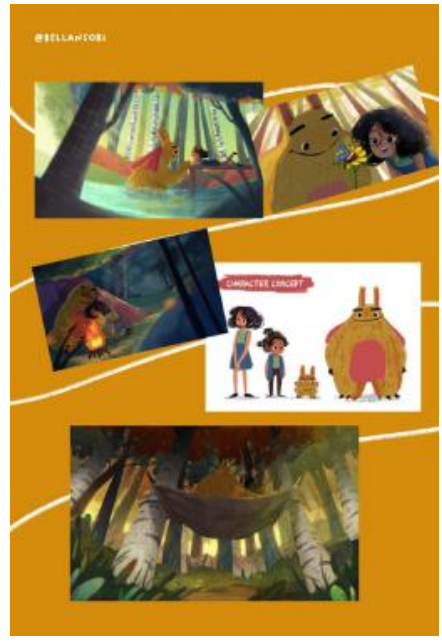

Gambar 6. Hasil karya Bella Ansori (Sumber: Bella, 2018)

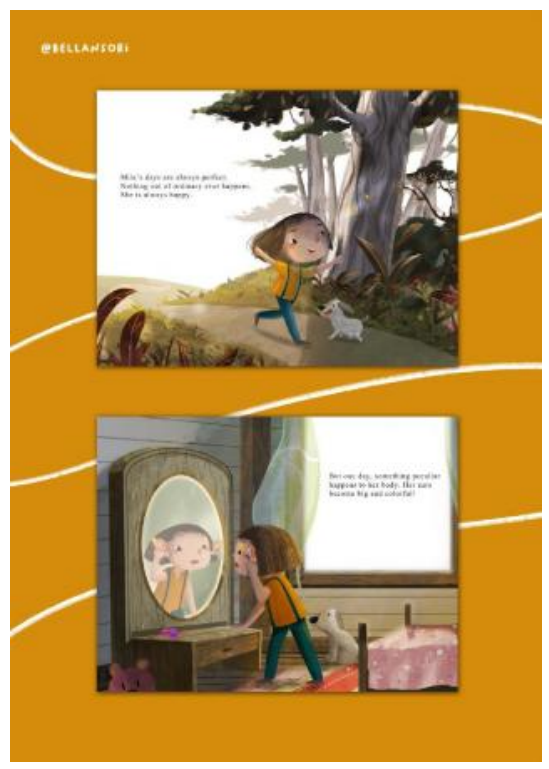

Gambar 7. Hasil karya Bella Ansori (Sumber: Bella, 2018)

\section{Optimisme Pencapaian}

Ilustrasi dalam bahasa Belanda (illustratie) diartikan sebagai hiasan dengan gambar atau pembuatan sesuatu yang jelas. Rata-rata penggunaan ilustrasi dalam buku dalam bentuk gambar kartun (Nurhadiat, Dedi, 2004:54). Ilustrasi hadir dengan tujuan untuk menyampaikan sebuah informasi yang ingin dicapai agar memudahkan para pembacanya dalam memaknai sebuah konsep, gagasan, dan nilai yang akan disampaikan dalam bentuk visual yang lebih menarik, komunikatif, dan memotivasi. Menurut Putra dan Lakoro (2012:2) ilustrasi pada sebuah buku bertujuan untuk menerangkan atau menghiasi suatu cerita, tulisan, puisi, atau informasi tertulis lainnya. Diharapkan dengan bantuan visual, tulisan tersebut mudah untuk dipahami.

Ilustrasi merupakan elemen utama dalam perancangan sebuah buku ilustrasi untuk anak. Ilustrasi akan membantu menstimulasi imajinasi dan kreativitas anak ketika membaca buku tersebut, sehingga diharapkan agar pembaca khususnya anak-anak tidak merasa sedang membaca sebuah buku tekstual yang konvensional. Selain itu buku ilustrasi anak dapat memainkan peran dalam menentukan kejadian penting dalam tumbuh kembang anak dari waktu ke waktu.

Menurut Bella Ansori buku ilustrasi anak merupakan media yang sangat efektif sebagai media yang merangsang imajinasi anak. Di 
samping itu media ini juga dapat digunakan untuk mengenalkan pendidikan moral, budaya, sosial, dan agama, serta sebagai alat untuk memicu perkembangan psikologi anak.

Bella Ansori sangat optimis dengan terciptanya karya-karya ilustrasi yang telah dirancangnya dapat mengubah perspektif masyarakat luas terhadap buku ilustrasi anak yang hingga dewasa ini masih dicap sebagai media hiburan semata menjadi media yang dapat membantu terpenuhinya hak-hak tumbuh kembang anak. Selain itu, ia juga berharap dengan hadirnya buku ilustrasi anak yang telah ia rancang ini dapat membantu orangtua dalam mendidik anak-anaknya, sekaligus dapat bermanfaat bagi lingkungan, bangsa, dan negara.

\section{KESIMPULAN}

Setiap permasalahan tentu memiliki solusi dalam pemecahan masalahnya, begitu pula permasalahan-permasalahan yang terjadi pada proses tumbuh kembang anak, khususnya perkembangan psikologisnya. Mencari solusi terbaik dalam memecahkan permasalahan pada anak bukan hanya tanggung jawab dari orangtua atau lingkungan keluarga, tetapi juga tanggung jawab dari seluruh kalangan masyarakat, bangsa, dan negara.

Bella Ansori mampu mengkolaborasikan seni dengan psikologi perkembangan anak untuk menghadapi problematika yang terjadi pada proses tumbuh kembang anak. Karyakarya yang diciptakannya dapat menggiring imajinasi dan menstimulasi kerja otak anak ke arah yang lebih positif. Kekhawatiran yang dirasakannya membuat setiap karya yang diciptakannya selalu memiliki nilai-nilai pendidikan psikologi dan pesan-pesan moral terhadap pembaca khususnya anak-anak.

Selain itu, buku ilustrasi anak yang telah ia rancang merupakan sebuah inovasi dalam menyadarkan masyarakat luas akan pentingnya perkembangan psikologi pada anak. Ia berhasil menciptakan sebuah media yang jarang dilirik oleh masyarakat Indonesia yang mayoritas masyarakatnya masih acuh dengan tingkat tumbuh kembang pada anak khususnya pada aspek psikologi.

Menurut Bella Ansori tugas seorang ilustrator maupun desainer adalah harus mampu memberikan manfaat kepada lingkungan, bangsa, dan negara dengan karya- karya yang telah diciptakannya. Tidak hanya menonjolkan sifat idealis praktis dari ilustrator atau desainer itu sendiri yang ujung-ujungnya hanya mengenyangkan perut sendiri. Ia juga berujar, karya-karya dari "kreator" haruslah bersifat provokatif positif, karya rancangan harus datang dari dalam jiwa yang didasari dari cara pandang perancang melihat problematika yang terjadi di masyarakat.

\section{KEPUSTAKAAN}

Creswell, J. W. 2016. Research Design:

Pendekatan Metode Kualitatif, Kuantitatif, dan Campuran. Yogyakarta: Pustaka Pelajar.

Elster, C. Simons, H. D. 1985. How important are illustrations in children's readers? New Jersey: Wiley.

Helms, D. B \& Turner, J.S. 1983. Exploring Child Behavior. New York: Holt Rinehartand Winston.

Indrijati, H. 2017. Psikologi Perkembangan dan Pendidikan Anak Usia Dini: Sebuah Bunga Rampai. Jakarta: Kencana.

Marliani, R. 2016. Psikologi Perkembangan Anak \& Remaja. Bandung: Pustaka Setia.

Nurhadiat, Dedi. 2004. Pendidikan Seni Rupa. Jakarta: PT Grasindo.

Putra, Antonius, N., Lakoro, Ramatsyam. 2012. Perangancang Buku Ilustrasi Musik Keroncong. Jurnal Teknik POMITS. Vol. 1.1 .

Rittie, R. 2000. The Verbal and Visual Components of Package Design. Journal of Product and Brand Management.

Tinarbuko, S. 2015. DEKAVE Desain Komunikasi Visual: Penanda Zaman Masyarakat Global. Yogyakarta: CAPS (Center for Academic Publishing Service).

\section{INFORMAN}

Bella Ansori (24), via telepon, 18 Oktober 2018 